\title{
Japanese foreign policy towards the Western Balkans: Kosovo crisis, instability in Macedonia, and European integration between 1998-2013
}

\author{
Marcela Perić \\ The Graduate School of Law, Keio University, Tokyo, Japan \\ marcela.peric01@gmail.com
}

\begin{abstract}
This study analyses Japan's Ministry of Foreign Affairs policies during the Kosovo crisis (1998), instability in Macedonia (2001), and Croatia's accession to the EU (2013). The human security concept enhances Japanese government's indirect approach through international organisations and expands its non-military capabilities of involvement in humanitarian crises and conflict prevention. During the ethnic conflict in Kosovo, non-belligerent promotion of human security expressed Japan's neutrality. The Kosovo crisis provided a new opportunity for Japan to advance political relations with the EU through the trilateral US-Japan-EU framework. Japan's contributions through human security and aid served as foundations for post-conflict reconstruction and development. International aid became the basis for transition towards a stable political system capable of building on its aspirations to become a member of the Western community of nations. By supporting EU enlargement in the Western Balkans, Japan fostered EU-Japan political relations, cross-regional cooperation, and peace in former Yugoslavia.
\end{abstract}

Keywords: EU, human security, Japanese foreign policy, Kosovo, Macedonia, Western Balkans

\section{Introduction}

The dissolution of the former Socialist Federal Republic of Yugoslavia (former SFRY or Yugoslavia) led to the ethnic wars in the Republic of Croatia (Croatia) (1991-95) and in the Federation of Bosnia and Herzegovina (Bosnia) (1992-95), which were settled by the Dayton Agreement. Kosovo was not included in the Agreement because it was an autonomous province in the Federal Republic of Yugoslavia (FRY, today the Republic of Serbia, henceforth referred to as Serbia). However, the Albanian question, pending since 1981, remained unresolved. ${ }^{1}$ With the binding problem of ethnic Albanians' rights after the conflict in Kosovo (1998), there was a humanitarian crisis and potential for conflict spill-over to the Former Yugoslav Republic of Macedonia

\footnotetext{
${ }^{1}$ E. Çeku, 'The Kosovo Demonstrations of 1981 and the Redefining of the Albanian Question', Diplomacy and Statecraft, Vol. 28, No. 2, June 2017, pp. 277-95. https://doi.org/10.1080/o9592296.2017.1309888.
} 
(today the Republic of North Macedonia, henceforth referred to as Macedonia) during the instability period in 2001.

When the Kosovo conflict broke out, many international actors were present in peacekeeping and humanitarian operations. This study focuses on Japan's neglected role in the Western Balkans. Since the Austrian Presidency of the Council of the European Union in 1998, the region of former Yugoslavia minus Slovenia plus Albania has been unofficially called the Western Balkans.2,3 Ethnic conflicts in the post-Cold War period caused instabilities throughout the region and could shift the foreign policies of Japan's neighbouring countries such as Russia and China, which could endanger Japanese foreign policy efforts in a larger context of interconnected regional security. The Kosovo crisis was a case in point.

The question is how and why Japan contributed to the peace efforts and post-conflict reconstruction in Kosovo and Macedonia, This study shows that the Kosovo crisis provided a new opportunity for Japan to advance political relations with the European Union (EU). Japan exercised its foreign policy in Kosovo and Macedonia through the existing trilateral US-Japan-EU framework showing unity with the West. 4,5 The involvement of Japan in European security is important for the development of political and economic cooperation with the EU, as envisioned in the Hague Declaration in 1991 and the Action Plan in 2001. 6,7,8 By aiding in the Kosovo humanitarian crisis, Japan could expect cross-regional cooperation from the EU regarding the situation on the Korean peninsula.9,10,11

After 'ensuring Japan's own security', the Japanese government's security was for 'promoting world peace and security with a comprehensive approach to conflicts'. ${ }^{12}$ Japan became one of the leading powers to contribute to conflict prevention since the enactment of the Act on Cooperation for United Nations Peacekeeping Operations and Other Operations (International Peace Cooperation Law) in June 1992. The three pillars of Japan's international peace cooperation were established: (1) UN Peacekeeping Operations, designed to resolve international conflicts by peaceful means; (2) contribution to international humanitarian relief operations; (3) international election observation operations with the objective of ensuring free and

\footnotetext{
${ }^{2}$ N. Beširević, Vanjska Politika Europske Unijei Zapadni Balkan [Foreign Policy of the European Union and the Western Balkans], Zagreb: Biblioteka politička misao, 2013, p. 102.

${ }^{3} \mathrm{Or}$ as a group of countries targeted by EU enlargement policy minus Croatia since 2013. European Cluster Collaboration Platform. EU Neighbourhood initiative in the Western Balkans.

https://www.clustercollaboration.eu/international-cooperation/western-balkans, accessed on $13^{\text {th }}$ June 2020.

${ }^{4}$ M. Peric, 'Japanese Foreign Policy Towards the Republic of Croatia: Preventive Diplomacy and Post-Conflict Reconstruction 1994-1997', Australian and New Zealand Journal of European Studies, Vol. 11, No. 2, December 2019, pp. 16-33.

${ }_{5}^{5}$ Building on the methodological framework in M. Peric, 'Japanese foreign policy towards the Republic of Croatia: The non-military practice of post-Cold War trilateralism and multilateralism 1989-1993', Japan Forum, (forthcoming, DOI 10.1080/09555803.2020.1808047)

${ }^{6}$ Y. Hosoya, 'The Evolution of the EU-Japan Relationship: Towards a 'Normative Partnership'?' Japan Forum, Vol. 24, No. 3, September 2012, pp. 317- 37. https://doi.org/10.1080/09555803.2012.699455.

${ }^{7}$ O. Frattolillo, Diplomacy in Japan-EU Relations: From the Cold War to the Post-Bipolar Era, London: Routledge, 2013.

${ }^{8}$ J. Gilson, EU-Japan Relations and the Crisis of Multilateralism, London and New York: Routledge, 2020.

${ }^{9}$ M. Reiterer, 'Japan and the European Union: Shared Foreign Policy Interests', Asia Europe Journal, Vol. 4, No. 3, February 2006, pp. 334-349. https://doi.org/10.1007/s10308-006-0075-1.

${ }^{10}$ K. Togo, Japan's Foreign Policy: The Quest for a Proactive Policy, Leiden: Brill, 2010.

${ }^{11}$ J. Keck, D. Vanoverbeke, and F. Waldenberger, EU-Japan Relations, 1970-2012: From confrontation to global partnership, London and New York: Routledge, 2013.

${ }^{12}$ MOFA, MOFA Diplomatic Bluebook, Tokyo: Ministry of Foreign Affairs, 2002.
} 
fair elections for the establishment of a legitimate ruling apparatus. Tools of cooperation are dispatch of personnel and contribution in kind, often combined. ${ }^{13}$ Due to its 'Peace Constitution', Japan could not send its Self-Defense Forces (SDF) to aid the international community in combat operations, but with International Peace Cooperation Law, the status of the SDF was regulated to help in non-combat situations and humanitarian relief operations. This gave Japan leverage to behave as a middle power, ${ }^{14}$ with non-military contributions in conflict prevention and resolution as a member of the international community. It is argued that the Japanese government utilised the concept of human security while defining its foreign policy. It served as a tool for implementation of pacifist diplomacy ${ }^{15}$ in post-conflict regions like Kosovo.

Previous research on Japanese foreign policy in Kosovo is an analysis of the government's 'complex engagement' - a multi-sectoral approach (through G7/8, UNHCR, UNICEF, and WHO) with non-military means which simultaneously addresses crises and post-crises situations at several levels. Goals of the nongovernmental organisations (NGOs) and Japanese government were merged, providing Japan with an opportunity to raise its non-military agenda in multilateral fora and establish a new foreign policy to achieve greater international recognition. ${ }^{16}$ Later, the concept of human security was established by Japan. ${ }^{17}$ Gilson and Purvis ${ }^{18}$ argued that Japan devised a humanitarian agenda and played a leading role in developing responses to non-traditional security threats. Having the 'safe umbrella of human security', Japan was able to make more constructive contributions in the international arena, from the Balkans to the Middle East and Afghanistan. Gilson and Purvis raised a critique of Japanese political pragmatism, claiming that the Japanese government uses human security to avoid controversial issues, such as human rights, instead of addressing them and also showing a lack of acceptance for the role of NGOs. ${ }^{19}$ Huliaras and Tzifakis ${ }^{20}$ argued that Japan and Canada had comparatively similar approaches to human security in the Balkans, apart from the use of military power. They argued that Japan's political objective of having a permanent seat in the UN Security Council was the main motivating factor in its aid to the Western Balkans. Further, factors such as the US pressure to share the rising burden of Balkan reconstruction and growing dialogue with the EU cannot be overlooked. ${ }^{21}$ Bechev agrees that Japan's role in the Western Balkans was overly political, ${ }^{22}$ and while the EU reinvented its foreign policy with the combination of soft- and hard-power resources, Japan mostly acted as a civilian power under the UN. ${ }^{23}$ "In summary, Japan adopted a

\footnotetext{
13 Government of Japan, Cabinet Office. Secretariat of the International Peace Cooperation Headquarters. http://www.pko.go.jp/pko e/cooperation/cooperation.html, accessed on $5^{\text {th }}$ of December 2019.

${ }^{14}$ Y. Soeya, 'Japanese Security Policy in Transition: The Rise of International and Human Security', Asia-Pacific Review, Vol. 12, No. 1, 2005, pp. 103-116. https://doi.org/10.1080/13439000500108208.

${ }^{15}$ Ibid.

${ }^{16}$ J. Gilson, 'Japan in Kosovo: Lessons in the Politics of 'Complex Engagement”, Japan Forum, Vol. 12, No. 1, 2000, pp. 65-75. https://doi.org/10.1080/09555800050059478.

${ }^{17}$ J. Gilson and P. Purvis, 'Japan's Pursuit of Human Security: Humanitarian Agenda or Political Pragmatism?', Japan Forum, Vol. 15, No. 2, 2003, pp. 193-207. https://doi.org/10.1080/0955580032000108388.

${ }^{18}$ Ibid.

${ }^{19}$ Ibid., p. 205

${ }^{20}$ A. C. Huliaras and N. Tzifakis, 'Contextual Approaches to Human Security: Canada and Japan in the Balkans', International Journal, Vol. 62, No. 3, September 2007, pp. 559-75.

${ }^{21}$ Ibid.

${ }^{22}$ D. Bechev, 'The EU, Japan and the Balkans: Cooperation for Post-conflict Nation-building' in P. Bacon, H. Mayer and H. Nakamura (eds.), The European Union and Japan: A New Chapter in Civilian Power Cooperation?, England and USA: Ashgate, 2015, p. 207.

${ }^{23}$ Ibid., p. 202.
} 
dual approach: a bilateral policy of assisting reform in post-communist countries and a contribution to multilateral efforts to contain violence in Yugoslavia”. ${ }^{24}$

This study builds on previous research with an argument that the human security concept was used in Japan's multilateral approach since the Kosovo crisis to express Japanese neutrality vis-à-vis the ethnic conflict. Japan's main concerns were the management of the humanitarian crisis and regional development. Further, it provides new information on the topic and includes Japan's overlooked role in Macedonia. The events are addressed chronologically to observe the under-researched developments in Japanese foreign policy in the Western Balkans. Primary resources in contemporary history such as Japan's Ministry of Foreign Affairs (MOFA) Diplomatic Bluebook and interviews with Ambassadors and diplomats are used to provide new data, together with Croatian, English, and Japanese secondary resources. First, the human security concept in Japanese foreign policy is defined and through the lens of EU-Japan relations, Japan's support for EU enlargement in the Western Balkans is analysed. Second, human security applications and Japan's role in resolving the Kosovo crisis are analysed. Finally, Japan's contribution during conflict prevention in Macedonia is observed.

\section{Japan-EU political cooperation in the Western Balkans}

While analysing Japan's role in the Western Balkans, EU-Japan relations in a larger context of trilateral US-Japan-EU relations is the starting point. ${ }^{25}$ After the Hague Declaration in 1991, the Action Plan in 2001 continued to institutionalise a new decade of cooperation between Japan and the EU. Frattolillo identifies eight areas in which the international crisis management operations have involved joint participation of Japan and the EU Commission: Cambodia, East Timor, Palestine, North Korea, Africa, Afghanistan, Iraq, and the Balkans. ${ }^{26}$ First, it is argued that the Japanese concept of human security is defined in line with Japan's non-belligerent and non-military capabilities. Secondly, the study argues that developments in Kosovo and Macedonia presented an opportunity for enhancing EU-Japan political cooperation. Compared with the situation in 1991, Japanese foreign policy expanded its means of resolving ethnic conflicts with the human security policy in place.

\subsection{Human security concept in Japanese foreign policy}

The human security concept became popular with the publication of the Human Development Report 1994 by the United Nations Development Programme. The concept's vagueness left scholars sceptical. ${ }^{27}$ However, this did not prevent governments from using the concept. The vagueness was an advantage as there was scope for redefinition. MOFA defines human security as "a concept that focuses on the strengthening of human-centred efforts from the perspective of protecting the lives, livelihoods, and dignity of individual human beings and realizing the abundant potential inherent in each individual" and specially stresses on factors contributing to

\footnotetext{
${ }^{24}$ Ibid., p. 206.

${ }^{25}$ Peric, op. cit.

${ }^{26}$ Frattolillo, op. cit., p. 61.

${ }^{27}$ H. Shinoda and H-W. Jeong, Conflict and Human Security: A Search for New Approaches of Peace-Building, Hiroshima University: Institute for Peace Science, 2004.
} 
the rise of terrorism, such as conflict and poverty. ${ }^{28}$ This vague definition seems to intentionally make space for confronting various fluid threats of the globalised world.

One of the aides of Japanese Prime Minister Keizo Obuchi, Keizo Takemi, noticed the threats of globalisation in the Asian financial crisis and saw the necessity to formulate and project a new future-oriented pacifism. The concept of 'one-country pacifism' was developed into peace diplomacy. It marks a departure from traditional security concepts and gives alternative solutions for Ozawa's 'normal country' argument. "What is particularly Japanese in Japan's context and approach to human security is that the motivation is closely connected with the desire to play a bigger role in international society under the assumption of proactive pacifism." ${ }^{29}$ Soeya argues that in the postCold War period, being able to rely on the US-Japan security alliance and engage more in international peace-keeping operations, Japan developed its foreign and security policy in the direction of middle power rather than traditional great power, without using either coercive or unilateralist tools. ${ }^{30}$ Due to the Second World War legacy, Japan needed to convince its neighbours that it is now a trading nation focused on promoting economic growth, with contributions to international security under multinational auspices. ${ }^{31}$ Through human security, Japan found a way to act as a responsible member of the international community. ${ }^{32}$

In December 1998, Prime Minister Obuchi first officially used the concept of human security in the context of Japanese foreign policy. Human security connected all global threats to humanity. Those threats are environmental problems, transnational crimes (drugs and human trafficking), influx of refugees from conflict areas, violations of human rights, infectious diseases such as AIDS, terrorism, anti-personnel landmines, and children bearing arms. Prime Minister Obuchi invited coordinated action by the international community to deal with the economic crisis in Asia.33 The same month the Prime Minister announced that a Trust Fund for Human Security would be established in the United Nations (UN) with a 500 million yen contribution from Japan, which was finalized in March 1999.34

Even after Prime Minister Obuchi's sudden demise in May 2000, human security continued to be one of the central concepts in Japanese foreign policy. Prime Minister Yoshiro Mori addressed the United Nations Millennium Summit in September 2000 and promoted Japanese foreign policy in the new 'human-centered century' with human security as the cornerstone of international cooperation in the $21^{\text {st }}$ century. ${ }^{35}$ As a response, the Commission on Human Security was established in January 2001, co-chaired by former United Nations High Commissioner for Refugees, Sadako Ogata, and Trinity College Professor, Amartya Sen. Prime Minister Mori said that the Japanese government is contributing an additional 10 billion yen to the 'Human Security Fund'. ${ }^{36}$ Through the Japan Center for International Exchange led by Tadashi

\footnotetext{
${ }^{28}$ MOFA, MOFA Diplomatic Bluebook, Tokyo: Ministry of Foreign Affairs, 2002.

${ }^{29}$ Soeya, op. cit., p. 108.

${ }^{30}$ Soeya, op. cit.

${ }^{31}$ R. J. Samuels, 'Securing Japan: The Current Discourse', The Journal of Japanese Studies, Vol. 33, No. 1, Winter 2007, p. 147.

${ }^{32}$ Soeya, op. cit.

33http://www.jcie.or.jp/thinknet/tomorrow/1obuchi.html, accessed on $29^{\text {th }}$ of November, 2019.

34 MOFA. 'Chronology of activities related to Human Security by the Japanese Government',

https://www.mofa.go.jp/policy/human secu/chronology.html, accessed on $29^{\text {th }}$ of November, 2019.

${ }^{35}$ MOFA, MOFA Diplomatic Bluebook, Tokyo: Ministry of Foreign Affairs, 2002, p. 89.

${ }^{36}$ Soeya, op. cit.
} 
Yamamoto, human security was promoted regionally and globally, involving NGOs, academics, journalists, politicians, bureaucrats, and business leaders. ${ }^{37}$

Akiyama argues that the Japanese government's approach towards human security has three major motives: (1) Japan needed to cope with changes in the international environment and promote its interests in the post-Cold War period; (2) aspiration for a permanent seat in the UN Security Council could be realised by promoting human security as Japan's contribution to international peace and security; (3) human security can be supported with Official Development Assistance, peacekeeping, and peace-building. ${ }^{38}$ This is why the concept of human security became the most important pillar of Japanese foreign and security policy in the new century, a concept that transcends governments, states, institutions, and regions.

\subsection{Japan and EU enlargement in the Western Balkans}

The biggest task in post-Cold War Europe was the transition of Central and East European countries from centrally planned economies and one-party systems to market economies and liberal democracies. Petrovic observed the uneven pace of democratic transition in communist Europe. ${ }^{39}$ Mikio Ikuma, Yomiuri Shinbun journalist who lived in Belgrade during the NATO bombing in 1999, noticed that in former Yugoslavia, Serbia (FRY) was especially slow in in adopting democratic systems and practices. Serbia had proclaimed democracy, but President Slobodan Milosevic's rule was autocratic, pushing the country into war in Yugoslavia. In 2000, after demonstrations and political revolution, President Vojislav Kostunica's task was to speed up Serbia's transition, and rebuild its country and people. However, the transition process was another invisible "wall" in Europe - an economic gap between West and East European countries ${ }^{40}$ becoming a crucial variable in future EU enlargement.

The Japanese government saw the Balkans as an opportunity for Japan to contribute to the creation of a new international order. The EU and Japan started to cooperate in the reconstruction of former Yugoslavia in the 1990s, making Japan the third largest donor after the EU and US. In 1992, Japan started to participate in the OSCE conferences, and in 1995, acquired the status of 'partner in cooperation' within the OECD where Japan contributed financially, participated in peace-building operations, and supported the reconstruction process in Bosnia. ${ }^{41}, 42$ This constituted Japan's indirect trilateral approach together with efforts through the UN and G7. ${ }^{43}$

\footnotetext{
${ }^{37}$ Soeya, op. cit.

${ }^{38}$ Shinoda and Jeong, op. cit.

${ }^{39}$ M. Petrovic, The Democratic Transition of Post-Communist Europe: In the Shadow of Communist Differences and Uneven EUropanisation, Place: The Palgrave Macmillan, 2013.

${ }^{40}$ M. Ikuma, 'Serubia Kakumei no Dejabu - Yuugo wa bundan wo kokufuku dekiru no ka [Serbia's Revolution

Deja-Vu: Can Yugoslavia Overcome the Divide?]', Gaiko Forum, Vol. 12. December. 2000, pp. 90-94.

${ }^{41}$ T. Inoguchi and P. Jain (eds.), Japanese Foreign Policy Today: A Reader, New York: Palgrave, 200.

${ }^{42}$ Frattolillo, op. cit., p. 62.

${ }^{43}$ Peric, op. cit., p. 21.
} 
Table 1: The UN, NATO, and EU members in the Western Balkans

\begin{tabular}{|c|c|c|c|c|c|c|}
\hline $\begin{array}{l}\text { Former } \\
\text { SFRY } \\
\text { republics } \\
\end{array}$ & Independence & $\begin{array}{c}\mathrm{UN} 44 \\
\text { member }\end{array}$ & $\begin{array}{l}\text { NATO member } \\
\text { (or status) }\end{array}$ & $\begin{array}{c}\mathrm{EU} \\
\text { candidature } \\
\text { (or status) }\end{array}$ & $\begin{array}{c}\text { Start of } \\
\text { negotiations } \\
\text { with the EU }\end{array}$ & $\begin{array}{c}\mathrm{EU} \\
\text { member }\end{array}$ \\
\hline Slovenia & 1991 & 1992 & 2004 & 1996 & 1997 & 2004 \\
\hline Croatia & 1991 & 1992 & 2009 & 2004 & 2005 & 2013 \\
\hline $\begin{array}{l}\text { Bosnia and } \\
\text { Herzegovina }\end{array}$ & 1992 & 1992 & $\begin{array}{l}\text { (2006 Partnership } \\
\text { for Peace) }\end{array}$ & $\begin{array}{c}(2003 \\
\text { potential } \\
\text { candidate })\end{array}$ & - & - \\
\hline $\begin{array}{c}\text { Serbia } \\
\text { (FRY) }\end{array}$ & $/ 45$ & 2000 & $/ 46$ & 2012 & 2014 & - \\
\hline Montenegro & $2003^{47} / 2006$ & 2006 & 2017 & 2010 & 2012 & - \\
\hline $\begin{array}{c}\text { North } \\
\text { Macedonia }\end{array}$ & 1991 & 1993 & 2020 & 2005 & 2020 & - \\
\hline Kosovo & 2008 & - & (1999 KFOR) & $\left(2016 \mathrm{SAA}^{48}\right)$ & - & - \\
\hline Albania49 & 1912 & 1955 & 2009 & 2014 & 2020 & - \\
\hline
\end{tabular}

Japan sent observers to monitor elections in 2004 in Kosovo. Japanese personnel's contributions to election monitoring and economic cooperation in Western Balkans are an acknowledgement of the conflict's impact on the whole international community, development of new norms and processes, and future relations between Japan and Europe in the context of enlargement. ${ }^{50}$ Japan also sent personnel to train the local police. Together with the EU, after organising the international conference on the consolidation of peace and economic development in April 2004, Japan helped to establish the international tribunal for war crimes. Aid to countries in the region continued, and the EU and Japan continued to cooperate in the Stability Pact for Southeast Europe with the aim of promoting security, democratisation, and economic development. $^{51}$

Croatia joined the EU in 2013 after Slovenia's entry in 2004. Having its first-time presidency of the Council of the EU from January to June 2020, Croatia was expected to facilitate enlargement in the region. Once engaged in war, Croatia is today perceived as a model for peace and democracy in the Western Balkans for countries hoping to join the EU. ${ }^{52}$ Misako Kaji, Japanese Ambassador in Croatia, stated the Japanese government's belief that Western Balkan countries' EU membership is the final phase of European integration and is of vital importance for peace and prosperity. ${ }^{53}$

\footnotetext{
44 UN. Member states. https://www.un.org/en/member-states/, accessed on 26th of June 2020.

45 The FRY denied that there was any new state in creation, making its non-recognition unusual. Other states did not deny FRY's statehood, but their legal position was that it did not continue the international personality of the SFRY. "The FRY was deemed to be a successor of the rights and duties of the SFRY - but not the continuator and non-recognition did not influence this question" (Vidmar 2013, 103).

${ }^{46}$ Serbia, the only country bombarded by NATO, will never join it (Glišić 2019).

47 In 1992, Montenegro and Serbia formed the FRY, which was transformed into the State Union of Serbia and Montenegro (SUSM) in 2003 (Vidmar 2013, 230).

48 Stabilization and Association Agreement (SAA) between Kosovo and the EU came into force on 1 April 2016. https://ec.europa.eu/neighbourhood-enlargement/countries/detailed-country-information/kosovo en, accessed on $11^{\text {th }}$ of June 2020.

49 Albania was not part of the SFRY; however, it is the only remaining country in the Balkans with foreign policy goals of NATO and EU membership and, therefore, is included in the table.

${ }_{50}$ MOFA, MOFA Diplomatic Bluebook, Tokyo: Ministry of Foreign Affairs, 2003.

${ }^{51}$ Frattolillo, op. cit.,

${ }^{52}$ D. Hrastić, 'Interview with Marcela Perić in the Embassy of Republic of Croatia, Tokyo', February 28, 2019. Held by the author.

${ }^{53}$ M. Kaji. 'Japan je ušao u novu 'eru stogodišnjaka', ljudi žele raditi i nakon 7o. godine [Japan entered into new era of 'hundred-year-olds', people want to work even after 70].' Večernji list, May 23, 2020.
} 


\section{Kosovo crisis}

The history of the Kosovo crisis stretches back to 1945 when Tito declared martial law in Kosovo, and continued as demonstrations at the University of Pristina in 1981 after Tito's death. ${ }^{54}$ After the Yugoslav wars (1991-95), the Dayton Agreement sponsored by the US provided settlement and a period of peace implementation. Vickers argues that not including Kosovo in this settlement became a disappointment for Kosovo Albanians and marks a turning point in their attitude towards resolutions of the Kosovo question. ${ }^{55}$.

Kosovo Albanians' Kosovo Liberation Army (KLA) funded largely by the diaspora ${ }^{56}$ with the ambition to create 'Greater Albania's7 declared Kosovo's independence from Serbia (FRY) in 1990, resulting in disbandment of the Autonomous Council and direct Serbian rule. When Serbia tried to defeat the KLA in 1998, the situation escalated. Serbia could not give up its southern province Kosovo, the founding place of the Serbian Orthodox Church, thereby linking Serbian identity and its claim to legitimacy. At this point, OSCE sent an observer mission to Kosovo. 58

In the Castle of Rambouillet, NATO Secretary General Javier Solana led peace talks in 1999. Peace talks failed because Serbia did not accept NATO forces for peacekeeping in Kosovo. Due to a deepening humanitarian crisis, NATO bombardment of Serbia commenced in March. Clashes between Serbia and the KLA continued, resulting in the outflow of refugees. By June, NATO bombardment ceased, and the UN Security Council adopted Resolution 1244 founding the United Nations Interim Administration Mission in Kosovo (UNMIK) under the protection of NATO's Kosovo Force (KFOR).59 The Japanese government was divided between a pro-UN approach and legalistic approach regarding bombardment of Kosovo. As an ally of the US, Japan needed to show solidarity but wanted to maintain its primary approach through the UN. That is why the "Japanese government 'understood' NATO's action, while it did not openly 'support' it”.60.

The Japanese government wanted to be involved in Kosovo for six reasons: (1) assistance as a response to the international commitment pledged by other industrialised nations (unity with the West); (2) since the Kosovo crisis was dealt with primarily through multilateral fora, Japan was left in charge of post-military activities; (3) the Kosovo case and promotion of humanitarian foreign policy offered a model for the Japanese role in Asia; (4) participation showed a commitment to the Western Balkans as part of advancing relations with the EU and fulfilment of the Hague Declaration goals; (5) Japan could count on the EU for support in Asia on a quid pro

\footnotetext{
${ }^{54}$ H. H. Perritt, Kosovo Liberation Army: The Inside Story of an Insurgency, Urbana and Chicago: The University of Illinois Press, 2008.

${ }^{55}$ J. Vidmar, Democratic Statehood in International Law: The Emergence of New States in Post-Cold War Practice, Oxford: Hart Publishing, 2013, p. 120.

${ }^{56}$ T. Judah, 'The Kosovo Liberation Army', Perceptions: Journal of International Affairs, Vol. 5, No. 3, September 2000, p. 65.

${ }^{57}$ Encyclopaedia Britannica. Kosovo Liberation Army. https://www.britannica.com/topic/Kosovo-LiberationArmy\#ref315172, accessed on $26^{\text {th }}$ of July, 2020.

${ }^{8}$ MOFA. Kosobo Kyouwakoku [Republic of Kosovo]. https://www.mofa.go.jp/mofaj/area/kosovo/data.html, accessed on $7^{\text {th }}$ and $10^{\text {th }}$ of December 2019.

59 Ibid.

${ }^{60}$ T. Ueta, 'Japan and the European Security Institutions', Studia Diplomatica, Vol. 54, No. 1/2, 2001, p. 134.
} 
quo basis; (6) the Kosovo crisis provided Japan with an opportunity to develop an alternative form of foreign policy through non-military means. ${ }^{61}$

Japan tried to play a mediator's role since it is not a NATO member. In April 1999, Prime Minister Keizo Obuchi asked Yasushi Akashi to meet President Milosevic and find a political role for Japan in the peace process. "Mr. Milosevic did not seem to understand Japan's sensitive position, which the Japanese statesmen defined as almost "neutral" (emphasis added). It did not work. Mr. Milosevic asked Mr. Akashi, as well as the other Japanese statesmen, to help in the reconstruction of Yugoslavia. In this regard, Japan cannot help other than in humanitarian assistance because of its solidarity with the West". ${ }^{62}$ Since the majority of the West perceived Serbia as an aggressor to Croatia, Bosnia and Herzegovina, and now Kosovo, and did not extradite President Milosevic to be put on trial for war crimes to the Hague Tribunal, Japan could not show its support to Serbia. What Japan could do was to provide humanitarian assistance to Serbia through a human security approach. In December 2000, the Japanese government lifted the sanctions against Serbia and Montenegro while maintaining sanctions against President Milosevic and his relatives. ${ }^{63}$ President Milosevic's extradition marked the beginning of a stabilisation period for Serbia. To facilitate regime change, the Japanese government extended aid to Serbia to secure conflict resolution and regional stability - over the fiscal years 1992 to 2000, 100 billion yen, and from 2001, \$50 million in grant aid to support reforms with $66 \%$ reduction in debt. High-level bilateral efforts were also made, including the February visit to Japan by Serbian Foreign Minister Goran Svilanovic and the July visit to Serbia by Foreign Minister Makiko Tanaka, where reform-related issues and the Kosovo and Montenegro issues were discussed. ${ }^{64}$

UNMIK's mandate operated as an interface of work-sharing responsibilities between international organisations. Japan was active in OSCE which served as UNMIK's pillar for institution building; the head of the European Union Rule of Law Mission in Kosovo was responsible for the rule of law, while KFOR handled security. The UN had overall authority. The UNMIK Mission had its Headquarters in Pristina and two field offices. One of the most important tasks was to secure the implementation of the UN Resolutions between the Headquarters in Pristina and the UN Office in Belgrade. 65 The greatest achievement of UNMIK is the promulgation of a Constitutional Framework for Provisional Self-Government in Kosovo, and the subsequent parliamentary elections. ${ }^{66}$ After fair and democratic elections, and decisions on power-sharing, in March 2002, the provisional government dominated by ethnic Albanians was established. "International actors aided Kosovo's transition to statehood allowing it to orient more and more towards a liberal democratic state". ${ }^{67}$

According to Yasuhito Murakami, one of the Japanese OSCE observers at the elections, electoral cooperation in support of the democratic elections also provides an opportunity for ethnic groups that have been in conflict with one another to come into contact in a non-confrontational manner. Counting of cast votes provided an opportunity for conflicted parties to work together. Murakami argues that the

\footnotetext{
${ }^{61}$ Gilson, Japan in Kosovo, op. cit., p. 73.

${ }^{62}$ Ueta, op. cit.

${ }^{63}$ Ueta, op. cit.

${ }^{64}$ MOFA, MOFA Diplomatic Bluebook, Tokyo: Ministry of Foreign Affairs, 2001, pp. 31-32.

65UNMIK. https://unmik.unmissions.org/mandate, accessed on $7^{\text {th }}$ of December, 2019.

${ }^{66}$ MOFA, MOFA Diplomatic Bluebook, Tokyo: Ministry of Foreign Affairs, 2002.

${ }^{67}$ Vidmar. op. cit., p. 136.
} 
implementation and administration of democratic elections provides opportunities for reconciliation that can lead to the realisation of peaceful multi-ethnic societies. ${ }^{6}$

"Based on the International Peace Cooperation Law, Japan dispatched more than 10 election observers to the Kosovo parliamentary elections. Since 1999, Japan has also provided a total of around US \$240 million in Kosovo-related assistance (including aid to the surrounding countries), including US $\$ 77$ million in humanitarian assistance for refugees and internally displaced persons, and around US $\$ 100$ million in reconstruction assistance, primarily for public broadcasting, housing, electricity, and education". ${ }^{69}$ According to Yoshifumi Okamura, former Japanese staff member of the UNMIK, the problem with Japanese aid was its visibility. ${ }^{70}$ While Kosovo started to look like an Olympic games site with flags from various nations dividing responsibility areas, the Japanese flag was nowhere to be seen because Japan could not send its SDF or police. The Japanese government provided $\$ 7$ million for the UNMIK plan for a severe winter. Japanese volunteers called 'Seventeen Samurai' helped the people of Kosovo to rebuild houses with their own hands, ${ }^{71}$ and brick factory Perparimi ensured employment for 200 workers under Japanese management. ${ }^{2}$

Kosovo declared independence on 17 February 2008.73 Recognition for this unilateral secession ${ }^{74}$ came from all former SFRY republics except Serbia, and Bosnia and Herzegovina. 75 During this time, Slovenia held the Presidency of the Council of the EU, and a protocol from a meeting with representatives of the US State Department leaked to the media, proved that Kosovo's declaration of independence was coordinated between Kosovo's leaders on the one hand and the US and EU on the other. It was recommended that independence be declared after the elections in Serbia and before Russia managed to call for the meeting of the UN Security Council. The US strived for recognition of Kosovo by as many non-EU states as possible and lobbied with Japan, Turkey, and Arab states which showed readiness to recognise Kosovo without hesitation. ${ }^{76}$ These political negotiations showed that the US-EU-Japan trilateral cooperation continued its efforts to settle conflict not only in Croatia and Bosnia ${ }^{77}$ but also in Kosovo. Japan recognised Kosovo as an independent country just one month later, on 18 March 2008; on 25 February 2009, diplomatic relations were established. $7^{8}$ With the recognition of Kosovo despite the wishes of Foreign Minister Masahiko Komura,79 Japanese relations with Serbia became tense, and it is still a stumbling block in Serbia's political relations with Japan. ${ }^{80}$ Serbia faces difficulty in

\footnotetext{
${ }^{68}$ MOFA, MOFA Diplomatic Bluebook, Tokyo: Ministry of Foreign Affairs, 2002.

${ }^{69}$ MOFA, MOFA Diplomatic Bluebook, Tokyo: Ministry of Foreign Affairs, 2002.

${ }^{70}$ Y. Okamura, 'Kosobo no Hi no Maru [Kosovo under the Rising Sun Flag]', Gaiko Forum, Vol. 5, May 2002, pp. 56-57.

${ }^{71}$ Okamura, op.cit.

${ }^{2}$ UN Trust Fund for Human Security. Rehabilitation of brick factory. https://www.un.org/humansecurity/wpcontent/uploads/2017/09/Programme-summary-32.pdf, accessed on 8th of December, 2019.

73 UNMIK. https://unmik.unmissions.org/mandate, accessed on $7^{\text {th }}$ of December, 2019.

74 Vidmar, op. cit.

75 Number of countries that have recognised Kosovo as an independent state is currently 113. Be in Kosovo. Countries that have recognized Kosovo as an independent state. https://www.beinkosovo.com/countries-thathave-recognized-kosovo-as-an-independent-state/, accessed on $11^{\text {th }}$ of June, 2020.

${ }^{76}$ Vidmar, op. cit., p. 126-27.

77 Peric, op. cit.

${ }^{78}$ MOFA. Kosobo Kyouwakoku [Republic of Kosovo]. https://www.mofa.go.jp/mofaj/area/kosovo/data.html, accessed on $7^{\text {th }}$ and $10^{\text {th }}$ of December 2019.

79 MOFA. Statement by Foreign Minister Masahiko Koumura on the Recognition of the Republic of Kosovo. https://www.mofa.go.jp/announce/announce/2008/3/0318.html Accessed 9 June 2020.

${ }^{80}$ N. Glišić, 'Interview with Marcela Perić in the Embassy of the Republic of Serbia, Tokyo', February 27, 2019. Held by the author.
} 
both demonstrating its commitment to EU integration and reciprocating Russia's support against Kosovo's international recognition. ${ }^{81}$

In 2008, the Japanese government and UN cooperated in designating a Trust Fund for Human Security to the Republic of Kosovo ${ }^{82}$ with an extension focused on community stabilisation in Northern Kosovo for economic opportunities and human rights protection for minority Serbian groups. All projects had common goals of enhancing multi-ethnic coexistence, reconciliation, and sustainable development in the region. This is how the Japanese government applied the human security concept to show its neutrality towards warring sides, Kosovo and Serbia.

\section{Instability in Macedonia}

The Japanese government has been involved in aiding Macedonia since the earthquake in Skopje which demolished 70\% of the city in 1963. When the UN published a tender for a new city plan, Japanese architect Kenzou Tange was selected which led to close cooperation between Macedonia and Japan. After the Cold War, there was concern in Japan about conflict spilling over from Kosovo. ${ }^{83}$ Albanian insurgents, the National Liberation Army (NLA) demanded improvements in the recognition of their ethnic status which led to attacks on the Macedonian police in 2001. The UN Security Council strongly condemned the extremist violence. MOFA sent letters "noting Japan's opposition to terrorism and violence and announcing that the international community would take concerted action to resolve the situation in Macedonia." 84

Japanese efforts were channelled through multilateral organisations in OSCE Spillover Monitor Mission to Skopje and the UN Preventive Deployment Force (UNPREDEP) mission from 1995 to 1999. The UNPREDEP was not renewed due to a veto from China in the UN Security Council. ${ }^{85}$ China is one of the countries that do not recognise Kosovo; its Embassy in Belgrade was hit during NATO bombardments and did not approve Macedonian recognition of Taiwan. ${ }^{86}$

After three months of instability, a coalition of national unity was formed representing all ethnic groups. NATO and the EU conducted a successful mediation process and the first national ceasefire agreement was signed. ${ }^{87}$ President Boris Trajkovski and the coalition signed the Ohrid Framework Agreement on 13 August 2001 with measures to improve the status of Albanians. The NLA gave up weapons to NATO and voluntarily dissolved. However, since the situation was still unstable, the UN Security Council granted powers to NATO troops to protect OSCE and EU monitors in Macedonia. Russia tried to undermine US and EU diplomatic efforts to resolve the political crisis

\footnotetext{
${ }^{81}$ F. Marciacq, 'Serbia: Looking East, going West?' in F. Bieber and N. Tzifakis (eds.), The Western Balkans in the World: Linkages and Relations with Non-Western Countries, Place: Routledge, 2020, pp. 78.

82 MOFA. Assistance by the United Nations Trust Fund for Human Security to the project "Multi-Sectoral

Initiative for Community Stabilization and Improved Human Security in Mitrovica and South Zvecan" in the Republic of Kosovo. https://www.mofa.go.jp/announce/announce/2008/10/1184463 1060.html, accessed on $9^{\text {th }}$ of June, 2020.

${ }^{83}$ I. Karanfilovski, (North Macedonian Changéd'Affaires ad interim to Japan) 'Interview with Marcela Perić in the Embassy of the Republic of North Macedonia, Tokyo', December 12, 2019. Held by the author.

84 MOFA, MOFA Diplomatic Bluebook, Tokyo: Ministry of Foreign Affairs, 2002, p. 33.

85 UNPREDEP recent developments. https://peacekeeping.un.org/mission/past/unpred r.htm, accessed on $11^{\text {th }}$ of June, 2020.

86 A. Vangeli, 'China: A new geo-economic approach to the Balkans' in F. Bieber and N. Tzifakis (eds.), The Western Balkans in the World: Linkages and Relations with Non-Western Countries, Routledge, 2020, pp. 208. 87 MOFA, MOFA Diplomatic Bluebook, Tokyo: Ministry of Foreign Affairs, 2002.
} 
in Macedonia because it sees NATO expansion as a threat to the Russian sphere of influence. $^{88}$

"Recognizing that the stability and development of Macedonia are crucial to the stability of all Southeast Europe, Japan - working in close cooperation with the EU and the US - is actively supporting the building of a multi-ethnic society in Macedonia based on political dialogue. At the Macedonia Donors' Meeting sponsored by the World Bank and the European Commission, held on March 12, 2002, Japan extended US \$10 million in grant aid to Macedonia. Other countries and organizations also made funding pledges, resulting in support totalling more than 300 million euro." 89 Japan continued to apply the US-Japan-EU trilateral cooperation framework in Macedonia after Kosovo.

Since Macedonia was not in as difficult a position as Kosovo, Japan did not have a chance to implement a human security program. Alternatively, aid served as a facilitator of peace; with three types of aid deployed: (1) financial loans with low interest rates, mainly to balance the budget; (2) technical cooperation projects with the Japan International Cooperation Agency and the Japan Bank for International Cooperation; (3) small grants up to 50,000 euro for activities such as renovating schools, hospitals, dispatching experts on work-share projects, and sharing Japanese knowledge with Macedonian institutions. Projects are focused on environmental protection, disaster prevention, waste management, and improving living conditions. ${ }^{90}$ President Trajkovski's visited Japan in 2003 and signed an agreement for the most important project, the Zletovica Hydrosystem which is ongoing. ${ }^{91}$ In return, Macedonia supports Japan to become a permanent member of the Security Council based on evaluating the Japanese contribution to Macedonia and the world. ${ }^{92}$

\section{Conclusion}

The last chapter in a decade-long Yugoslav crisis was the ethnic conflict in Kosovo and its potential spill-over to Macedonia. Together with the politics of 'complex engagement' in Kosovo, ${ }^{93}$ this study expanded the topic with Japan's involvement in Macedonia and placed emphasis on the human security concept and aid in Japan's multilateral approach. Kosovo is considered a test case for proving the validity of the human security approach. 94 Human security served the Japanese government to enhance its indirect approach through international organisations (UN, OSCE, and EBRD). Although its use may seem pragmatic, human security is considered as a tool to expand Japan's non-military capabilities of involvement in humanitarian crises and conflict prevention policy, expressing Japanese neutrality during ethnic conflicts.

\footnotetext{
${ }^{88}$ Z. Nechev and I. Nikolovski, 'North Macedonia: A Fertile Ground for External Influences' in F. Bieber and N. Tzifakis (eds.), The Western Balkans in the World: Linkages and Relations with Non-Western Countries, London and New York: Routledge, 2020, pp. 127.

${ }^{89}$ MOFA, MOFA Diplomatic Bluebook, Tokyo: Ministry of Foreign Affairs, 2002.

${ }^{90}$ Karanfilovski, op. cit.

${ }^{91}$ A. C. Huliaras, 'Japan and South Eastern Europe', Journal of Southern Europe and the Balkans, Vol. 9, No. 1, Month 2007, pp. 15-27. https://doi.org/10.1080/14613190701216920.

92 UNPREDEP recent developments. https://peacekeeping.un.org/mission/past/unpred r.htm, accessed on $11^{\text {th }}$ of June 2020.

93 Gilson, Japan in Kosovo, op. cit.

94 Statement by H.E. Mr. Yukio Takasu, Permanent Representative of Japan, at the Meeting of the Security

Council on Resolution 1160 (1998), 1199 (1998), 1203 (1999) and 1244 (1999).

https://www.mofa.go.jp/announce/speech/un2009/uno903-10.html, accessed on $9^{\text {th }}$ of June, 2020.
} 
The Japanese government expressed solidarity with the West in US-Japan-EU trilateral cooperation consultations regarding Kosovo's independence. Japan and the EU created a model of interaction as global partners. ${ }^{95}$ In Macedonia, trilateral cooperation had the goal of improving stability and development. The situation in Macedonia did not demand a human security approach, resulting in deployment of aid as a tool for building stability. Nevertheless, both human security and aid served as foundations for post-conflict reconstruction and development, promoting trade and FDI, and rebuilding society with Euro-Atlantic ambitions. Japan exercised its foreign policy in the Western Balkans, via tools of human security, peace diplomacy, and aid as a non-military power.

The motivation for Japan's involvement in the Western Balkans stems from a comprehensive outlook. MOFA acknowledged that (1) conflicts have an impact not only on Europe but also the international community as a whole; (2) efforts in regard to the Balkan conflict contribute to Japan's participation in the formation of new international mechanisms; (3) strengthening relations with the Balkan countries as potential members of the EU is important for future Japan-EU relations; (4) Japan's efforts in former Yugoslavia led to the strengthening of Japan-EU cooperation and vice versa European efforts in regard to Asian issues via cross-regional support. ${ }^{96}$ Japan and the EU can counterbalance Russia ${ }^{97}$ and China's ${ }^{98}$ growing geopolitical and economic interests in Western Balkans.

The main political tasks in the Western Balkans for future EU enlargement are further political rapprochement between Croatia and Serbia, and continuous dialogue and normalisation of relations between Kosovo and Serbia. Japanese investments and political support for EU integration reflect on EU-Japan relations and provide incentives for cross-regional cooperation. Supporting Albania, Bosnia and Herzegovina, Kosovo, Macedonia, and Serbia's path towards the EU is considered by the Japanese government as a final phase of European integration. Today, with the 'Western Balkans Cooperation Initiative', 99 Japan continues its contributions in Europe.

\footnotetext{
${ }^{95}$ Frattolillo, op. cit. p. 62.

${ }^{96}$ MOFA, MOFA Diplomatic Bluebook, Tokyo: Ministry of Foreign Affairs, 2001.

${ }^{97}$ Marciacq, op. cit.

${ }^{98}$ A. Vangeli, 'China: A new geo-economic approach to the Balkans' in F. Bieber and N. Tzifakis (eds.), The

Western Balkans in the World: Linkages and Relations with Non-Western Countries, Routledge, 2020, pp. 205224.

99 MOFA. Japan-Serbia Summit Meeting. https://www.mofa.go.jp/erp/c see/serbia/page1e 000197.html;

MOFA. "Western Balkans meet Japan: A Bridge into the Future." https://www.rycowb.org/wp-

content/uploads/2019/o9/MIRAI Overview-of-the-program 2019.pdf, accessed on 21st of June, 2020.
} 
Copyright of Australian \& New Zealand Journal of European Studies is the property of Contemporary European Studies Association of Australia (CESAA) and its content may not be copied or emailed to multiple sites or posted to a listserv without the copyright holder's express written permission. However, users may print, download, or email articles for individual use. 